\title{
Incidence of milk leakage after dry-off in European dairy herds, related risk factors, and its role in new intramammary infections
}

\author{
A. I. De Prado-Taranilla, ${ }^{1}$ M. M. C. Holstege,${ }^{2}$ L. Bertocchi, ${ }^{3}$ A. Appiani, ${ }^{4}$ O. Becvar, ${ }^{5}$ J. Davidek, ${ }^{5}$ D. Bay, ${ }^{6}$ \\ L. M. Jimenez, ${ }^{7}$ N. Roger, ${ }^{7}$ V. Krömker, ${ }^{8}$ J. H. Paduch, ${ }^{8}$ S. Piepers, ${ }^{9}$ A. Wuytack, ${ }^{9}$ A. Veenkamp, ${ }^{10}$ \\ T. van Werven, ${ }^{11}$ B. Dalez, ${ }^{12}$ P. Le Page, ${ }^{13}$ Y. H. Schukken, ${ }^{2}$ and A. G. J. Velthuis ${ }^{2 *}$ \\ ${ }^{1}$ CEVA Santé Animale, Avenue de la Ballastière, 33500 Libourne, France \\ ${ }^{2}$ GD Animal Health, PO Box 9, 7400 AA Deventer, the Netherlands \\ ${ }^{3}$ Italian National Reference Centre for Animal Welfare, Istituto Zooprofilattico Sperimentale della Lombardia e dell'Emilia Romagna, \\ Bruno Ubertini, Via A. Bianchi 9, 25124 Brescia, Italy \\ ${ }^{4}$ Embryo Vet Studio Veterinario, Cascina Bosco 6, 25028 Verdanuova (Brescia) Italy \\ ${ }^{5}$ FarmVet spol.s. r.o., Rojšín 5, 38203 Brloh, Czech Republic \\ ${ }^{6}$ Department of Veterinary and Animal Sciences, University of Copenhagen, Grønnegårdsvej 2, 1870 Frederiksberg C, Denmark \\ ${ }^{7}$ Servet Talavera S.L., Plaza San Andrés, 15, 45600 Talavera de la Reina, Toledo, Spain \\ ${ }^{8}$ Faculty II, University of Applied Sciences and Arts, Department of Bioprocess Engineering, Heisterbergallee 10A, 30453 Hannover, Germany \\ ${ }^{9}$ M-team and Mastitis and Milk Quality Research Unit, Faculty of Veterinary Medicine, Ghent University, Salisburylaan 133, B-9820, \\ Merelbeke, Belgium \\ ${ }^{10}$ Van Reen Cattle Veterinarian et Dierenartsenpraktijk, Flevoland, Gildenveld 76, 3892 DJ Zeewolde, the Netherlands \\ ${ }^{11}$ Department of Farm Animal Health, Utrecht University, Yalelaan 7, Utrecht $3584 \mathrm{CL}$, the Netherlands \\ ${ }^{12}$ Réseau Cristal, SELAS EVA, Argentonnay 79150, France \\ ${ }^{13}$ Clinique Vétérinaire LesVet, 3 Place du Champ de Bataille, 29260 Lesneven, France
}

\section{ABSTRACT}

The incidence of milk leakage (ML) after dry-off (DO) and related risk factors was studied in 1,175 dairy cows from 41 commercial herds in 8 European countries: Belgium, Czech Republic, Denmark, France, Germany, Italy, the Netherlands, and Spain. Milk leakage was assessed twice for $30 \mathrm{~s}$ each during 3 visits at 20 to $24 \mathrm{~h}, 30$ to $34 \mathrm{~h}$, and 48 to $52 \mathrm{~h}$ after DO. Information related to dry-cow management and udder health was collected at herd and cow level, including individual somatic cell count (ISCC) from test-day controls and occurrence of clinical mastitis cases from DO until 30 $\mathrm{d}$ in lactation. Mixed-effect logistic regression analyses were used to identify possible risk factors for ML and to study the association between ML and new intramammary infections. Intramammary infections were defined as clinical mastitis cases during the dry period and in the first $30 \mathrm{~d}$ in lactation or a rise in ISCC from before to after the dry period (threshold: 200,000 cells/mL) or both. Milk leakage was observed in $24.5 \%$ of the cows between 20 and $52 \mathrm{~h}$ after DO, where the herd incidence varied between 0.0 and $77.8 \%$. The reduction in number of milkings in the weeks before DO had statistically significant effect on the ML incidence. When the milking frequency was reduced from 3 times/d to

Received December 19, 2019.

Accepted May 11, 2020.

*Corresponding author: a.velthuis@gddiergezondheid.nl
2 or maintained at twice a day, cows had $11(95 \% \mathrm{CI}$ $=3.43-35.46)$ or $9(95 \% \mathrm{CI}=1.85-48.22)$ times higher odds of leaking milk, respectively, compared with cows where the milking frequency was reduced from twice to once a day. Also, the milk production $24 \mathrm{~h}$ before DO was associated with ML incidence. Hence, cows with a milk production between 13 and $21 \mathrm{~L}$ or above $21 \mathrm{~L}$ had $2.3(95 \% \mathrm{CI}=1.48-3.53)$ and $3.1(95 \% \mathrm{CI}=1.79-5.3)$ times higher odds of leaking milk, respectively, compared with cows with a milk production below $13 \mathrm{~L}$. A higher ML incidence was present in the group of cows with an average ISCC in the last 3 mo before DO $\geq 200,000$ cells $/ \mathrm{mL}$ (odds ratio $=1.7 ; 95 \% \mathrm{CI}=$ 1.13-2.41) compared with cows with an average ISCC $<100,000$ cells $/ \mathrm{mL}$. Quarters with ML tended to have 2.0 times higher odds of developing clinical mastitis compared with quarters not leaking milk. Cows with ML tended to have 1.5 times higher odds of intramammary infections (i.e., an increase of ISCC or clinical mastitis) compared with cows without ML.

Key words: milk leakage, dry-off, risk factor, intramammary infection, clinical mastitis

\section{INTRODUCTION}

A dry period with an appropriate length is needed to maximize productivity in the next lactation (Neave et al., 1950; Sørensen and Enevoldsen, 1991; Weber et al., 2015). The transition from lactation to dry period has been widely recognized as a critical time in the 
production cycle of dairy cows (Capuco and Akers, 1999; Bachman and Schairer, 2003; Choudhary, 2014). Immediately after the cessation of milking, the cisternal spaces, ducts, and alveoli of the gland are engorged with milk that is not going to be milked out. This is followed by a regression of the secretory activity of the epithelial cells until involution of the gland tissue is completed. The slow transition to the involute state delays the protective effects of lactoferrin and immunoglobulins, and fat and casein levels remain high, inhibiting leukocyte function (Sordillo and Nickerson, 1988; Collier et al., 2012; Boutinaud et al., 2017). With the increase of milk yield over the last decades, the modern dairy cow may produce 25 to $30 \mathrm{~kg} / \mathrm{d}$ of milk at the time of dry-off (DO; Stefanon et al., 2002). For that reason, it has been suggested that drying-off has become more challenging for cows in respect to their health and welfare (Thornton, 2010; Zobel et al., 2015).

The accumulated milk in the udder increases the udder volume and pressure and can cause discomfort and pain (Bach et al., 2015; Bertulat et al., 2017). It has been hypothesized that there is an association of high milk production and decreased teat-canal closure by a keratin plug. This plug is a natural defense mechanism that prevents bacteria and other pathogens from entering the udder via the teat canal during the dry period. This sealing process takes time, and in $47 \%$ of cases it is not finished within the first week of the dry period (Dingwell et al., 2004). Additionally, the high milk yield at DO may also increase the risk of new IMI (i.e., an increase of ISCC from before DO to calving or bacteria present in the milk sample at calving), and an increase of the risk of milk leakage (ML; Dingwell et al., 2001; Huxley et al., 2002; Rajala-Schultz et al., 2005; Rovai et al., 2007).

The National Mastitis Council recommends lowering milk production below $15 \mathrm{~L} / \mathrm{d}$ before DO (NMC, 2006). Reduction of milk production may be achieved with a gradual DO by reducing the quality or quantity of feed, the frequency of milking during the last day of lactation, or both (Tucker et al., 2009; Ollier et al., 2014; Gott et al., 2016). However, changing the feeding before DO may cause health issues due to a temporary state of a negative energy balance (Odensten et al., 2005), which can lead to health disorders such as mastitis (Ingvartsen et al., 2003). Another method to reduce milk production is the use of prolactin-release inhibitors, such as cabergoline (Bach et al., 2015), that hasten mammary gland involution, enhance immunity (Boutinaud et al., 2016, 2017), and significantly $(P<$ 0.000) reduce the risk of ML (Hop et al., 2019).

The incidence of ML was reported to be $30 \%$ by Schukken et al. (1993), who also showed that it was associated with an increased risk of new IMI during the dry period. In a more recent study, Zobel et al. (2013) observed an ML incidence of $27 \%$ in cows that were gradually dried off compared with $75 \%$ in cows that were dried off abruptly. Hop et al. (2019) found ML in $15 \%$ of cows treated with antibiotic dry-cow therapy compared with $11 \%$ of cows not treated. Other factors have also been found to be associated with ML. Short teats, inverted teat ends, and teat-canal protrusions increased the risk of ML in multiparous cows (Klaas et al., 2005). Although ML appears to be an important indicator of the risk of new IMI in the dry period, studies reporting on the incidence of ML, its association with factors such as teat-end score or milk production, and its relationship with new IMI during the dry period and after calving are scarce. Therefore, the objective of this study was to investigate the ML incidence from DO to $52 \mathrm{~h}$ later in commercial European dairy herds, related risk factors, the association between ML and new IMI, and the presence of clinical mastitis (CM) across the dry period and in the first $30 \mathrm{~d}$ after calving.

\section{MATERIALS AND METHODS}

\section{Selection of Herds and Cows}

Herds in Belgium, Czech Republic, Denmark, France, Germany, Italy, the Netherlands, and Spain were selected via the network of the authors. The herds had to meet the following criteria: (1) have cows with an average $305-\mathrm{d}$ milk production $>8,000 \mathrm{~L}$ or an average of $25 \mathrm{~L} / \mathrm{d},(2)$ have a satisfactory system in place for individual cow identification and recording of individual cow health data where CM treatments could be differentiated, (3) have milk meters measuring milk weights daily, (4) have monthly records of individual SCC (ISCC) for at least 3 mo preceding enrollment of the first cow, and (5) have a fixed DO protocol.

Cows were eligible for enrollment if they (1) were in good health at inclusion, with no signs of suffering from any infectious or metabolic diseases; (2) had no signs of $\mathrm{CM}$ at inclusion (no clinical signs in the quarter, such as swelling, heat, or pain; no changes in the appearance of milk, such as clots or flakes, watery appearance, or discoloration), and no systemic signs of disease, such as fever or loss of appetite; (3) had 4 functional quarters at inclusion; (4) were not treated with internal or external teat seal at the moment of DO; and (5) had recorded ISCC for at least 3 mo before DO.

\section{Study Design}

To optimize an equal distribution over the involved countries, a minimum number of enrolled cows was set at 140 per country at 1 or more study sites (herds) 
betweens December 2014 and May 2015. Fourteen veterinarians from the 8 European countries, specialized in milk quality, were in charge of herd and cow recruitment and data collection. Cows that qualified were enrolled in the study from the day of the DO until 30 $\mathrm{d}$ after calving. During this period, cows were managed according to normal practices on the farm, including mastitis treatments used for the analysis.

The following retrospective information from the herds was recorded a few weeks before the first cow of each farm was enrolled the study: number of cows (total, lactating, and dry), average milk production per cow per year and annual average milk production per cow per day, type of milking parlor, number of milkings per day, whether a teat dipping is used after milking, housing of dry cows (including space per animal), bedding for the dry cows and cleaning frequency, the bulk milk SCC (BMSCC) of the previous 3 mo (3 counts), the incidence of $\mathrm{CM}$ per month, and the known mastitis bacteria present at the farm.

Other information collected about the DO strategy at herd level was the average milk production per cow per day at $\mathrm{DO}$; the timing of the DO moment on a weekly basis (and if this is a fixed moment); whether the DO is abrupt or gradual, including a description of the diet and the availability of drinking water in the week before DO; the general applied dry-cow treatment strategy, including the use of intramammary antibiotics, parenteral antibiotics, and internal or external teat sealant; and the criteria used to determine the DO moment, including a threshold for milk production, days of pregnancy, and others. At the end of the field phase, farmers were asked another set of questions regarding the abrupt or gradual DO strategy. Those questions included the following: Are the number of milkings per day reduced at the end of the lactation? And when did you start to reduce the number of milkings? Is the feeding strategy changed at the end of lactation? And when did you change the feeding strategy?

The following information from the included cows was recorded at the day of DO: age, parity, expected calving date, current lactation yield, number of milkings the last day before DO, milk yield during the last $24 \mathrm{~h}$ before the DO (i.e., the sum of the milk production of each milking the last day of lactation), teat-end score, whether the individual cow was treated with dry-cow antibiotic, ISCC measured once a month for 3 mo before DO, and recorded cases of CM in the $30 \mathrm{~d}$ before DO.

Milk leakage observations were performed by investigators who visited the herds regularly. The ML observations were at quarter level during visits at 20 to $24 \mathrm{~h}, 30$ to $34 \mathrm{~h}$, and 48 to $52 \mathrm{~h}$ after DO. Observations were mostly done in the morning after the first milking.
The observation was done for 2 periods of $30 \mathrm{~s} / \mathrm{visit}$ using a flashlight. To ensure proper observation, cows had to stand in headlocks, and if a cow was lying down, she was kindly chased up and observed for ML. Milk leakage was considered to be present when (1) a stream of milk was coming from the teat, (2) milk drops were visible on the teat end, or (3) milk was observed on the ground beneath the udder (in this case no quarter was specified). A final visit or database checkup was carried out at any time between 30 and $60 \mathrm{~d}$ after the cow calved to record the ISCC values and CM cases that had been observed and recorded by the farmer during the study period. Bacteriological data were not available.

Quarters were withdrawn from the study if they suffered from an injury, were trodden on, or became dysfunctional for other reasons during the study period (i.e., from DO to $30 \mathrm{~d}$ postcalving) as the incidence of ML and new IMI may be different in dysfunctional quarters. Cows were withdrawn from the study if they were removed from the herd for any reason during the study period. Other actions that could affect the quality and integrity of the study were also recorded and documented.

To guarantee a standard approach and good data collection, the investigators involved in the study were trained on the study protocol, including standard operation procedures, and on how to use the online database for data entry before starting the study. No intra- or interobserver calibrations were performed. Complete recordings of the observations and recordings were entered into an electronic database and checked automatically on various points to ensure the accuracy of the data. Corrections were made both on the original form by hand and in the electronic database and included a description of the correction, date of the correction, and corrector.

\section{Primary and Secondary Outcomes}

Three models were built. The primary model was the incidence of ML in the first $52 \mathrm{~h}$ after DO. Milk leakage should be considered positive if any of the 4 quarters was leaking milk during at least one observation during visits at 20 to $24 \mathrm{~h}, 30$ to $34 \mathrm{~h}$, and 48 to $52 \mathrm{~h}$ after DO. A possible difference in the ML incidence risk between front and rear quarters was investigated using logistic regression. The secondary outcomes were the possible associations between (1) ML and recorded CM cases from DO up to first $30 \mathrm{~d}$ in lactation, and (2) ML and new IMI (defined as an increase of the ISCC from $<200,000$ cells $/ \mathrm{mL}$ at the last record before DO to $\geq 200,000$ cells $/ \mathrm{mL}$ at the first record after calving, the presence of $\mathrm{CM}$ in one or multiple quarters from 
DO up to $30 \mathrm{~d}$ after calving, or both). Note that cows were only eligible for new IMI results if they had a cell count $<200,000$ cells $/ \mathrm{mL}$ during the last testing before DO; cows with ISCC $\geq 200.000$ cells $/ \mathrm{mL}$ were not included as they were considered already infected at DO. Risk factors such as teat-end score, husbandry practices, parity, and milk production were also studied to determine any relationship to the presence of ML.

\section{Statistical Analysis}

Stata 14.0 (StataCorp LLC, College Station, TX) was used for the statistical analysis. Descriptive analysis included (1) incidence of ML after DO at country, herd, cow, and quarter level (with corresponding 95\% CI); (2) the number of quarters leaking milk per cow; and (3) the distribution of ML over the different quarters. The same descriptive statistics were calculated for CM at cow and quarter level for both during the dry period and after calving, as well as for the estimated incidence of a rise in cell count and the new IMI at cow level.

Mixed-effects logistic regression models were used to investigate risk factors for ML at quarter and cow level, the association between ML and CM at quarter and cow level, and the association between ML and new IMI at cow level. Random effects were included for cows (quarters were nested within cows) and herds (cows were nested within herds). In models with a random herd effect, only herds with a minimum of 5 cows enrolled were included. The country was included in the model selection as a fixed effect and not as a random effect, due to the low number of categories allowing for the investigation of country specific coefficients and the low number of herds per country in some cases (though the number of cows per country was sufficient). To also gain insight into the relative correlation within cows, herds, and country with regard to the dependent variables, we added country as a random effect to the final multivariable model and checked whether the model would improve significantly. When country was already accounted for in the final model as a fixed effect, it would be excluded for this purpose.

Univariable models were fitted for all possibly relevant independent variables. Independent variables with $P \leq 0.20$ were candidates for the multivariable model selection. Multicollinearity was assessed for these candidates using a spearman correlation matrix. When multicollinearity was present (rho $\geq 0.5$ ), variables with lower $P$-values were preferred and taken into account during multivariable model selection. Multivariable model selection started at quarter level. When significant associations $(P \leq 0.05)$ were not present at quarter level, model selection continued at cow level. A manual forward-stepwise selection method was used, accounting for confounding ( $>25 \%$ change in coefficient of already-present variables). Biologically relevant 2 -way interactions were tested in the models when possible with regard to sufficient numbers of observations.

\section{RESULTS}

\section{Study Population: Herds, Cows, and Quarters}

In total, 1,189 cows from 41 commercial dairy herds in 8 European countries (Belgium, Czech Republic, Denmark, France, Germany, Italy, the Netherlands, and Spain) were enrolled in this study. Fourteen investigators were responsible for the data collection. On average, 29 cows were enrolled per herd and 146 per country. Fourteen cows were removed from the data due to one or more nonlactating teats. Consequently, the number of eligible cows and quarters for analysis was 1,175 and 4,684, respectively; ML registrations were incomplete for 4 cows. Sixty-five cows were removed from the study mainly due to emergency culling or slaughter; however, 17 cows and 140 quarters in all were excluded from (some) statistical analyses due to missing information on one or more variables used in the statistical models.

\section{Descriptive Statistics}

Table 1 gives information on individual herds, including herd size and production characteristics. The herds varied greatly in herd size (average 265 lactating and dry cows), herd average milk production per cow per year $(9,494 \mathrm{~L})$, and average BMSCC of the 3 values of the previous 3 mo $(237,000$ cells $/ \mathrm{mL})$. There were 2 herds with an average milk production per cow per year below the 8,000 L included. One farm had an average milk production of $7,500 \mathrm{~L}$, due to the inclusion of $>100$ low-production cows to the herd in the year before the trial started, but the average had increased at the start of the field phase as low-production cows were culled by then. The other farm had an average milk production at inclusion of $7,800 \mathrm{~L}$ because it had reproductive problems in the year before, but the cows with problems were culled before starting this study. The milk production per year for the included cows of these 2 herds was on average 8,126 L and 9,484 $\mathrm{L}$ and did not significantly differ from the milk production per cow per year from included cows of the other herds.

A description of characteristics of the DO management is given in Table 2. Although 6 herds (14.6\%) normally use teat sealers at DO, none of the cows included from these herds were treated with internal or external teat sealers in this study. Thirty-one herds (75.6\%) applied an abrupt DO (i.e., did not change 
the management with the objective of reducing the milk production before DO); however, $57.1 \%$ of those farmers changed the feeding strategy (either quantity or quality of feed) days or weeks before milking for the last time.

In some of the herds where the feeding strategy was changed, the number of milkings also was reduced (6 out of 16). Farmers started reducing the number of milkings at different times: $14 \mathrm{~d}$ or 9 to $1 \mathrm{~d}$ before DO. In regard to the milk production at DO, $31.6 \%$ of the cows produced $<13 \mathrm{~L}$ during the last $24 \mathrm{~h}$ before DO, $40.5 \%$ produced $\geq 13$ but $<21 \mathrm{~L}$, and $27.9 \%$ produced $\geq 21 \mathrm{~L}$.

The cows had an average parity of 2.1 (range $=$ 1-8) with an average current lactation yield of 10,556
$\mathrm{L}$ (range $=3,200-25,741 \mathrm{~L}$ ), and their registered dry period lasted on average $59 \mathrm{~d}$ (range $=8-161 \mathrm{~d}$ ). The average ISCC in the last 3 mo before DO was on average 234,200 cells $/ \mathrm{mL}$ and varied between 8,000 and 4,223,000 cells/mL.

The teat-end score of all 4,700 quarters enrolled in this study is summarized in Table 3 . Results show that $42.1 \%$ of the quarters had no ring, $38.9 \%$ had a smooth ring, $14.8 \%$ had a rough ring, and $4.1 \%$ had a very rough ring.

\section{Incidence of ML at Cow Level}

Milk leakage in 1 or more teats at 1 or more observation times was observed in 287 out of 1,171 cows (ML

Table 1. Characteristics and observed milk leakage (ML) of the 41 included herds

\begin{tabular}{|c|c|c|c|c|c|c|c|c|}
\hline \multirow[b]{2}{*}{ Country } & \multirow[b]{2}{*}{$\begin{array}{l}\text { Cows } \\
\text { in herd } \\
\text { (no.) }\end{array}$} & \multicolumn{3}{|c|}{ Average milk production } & \multirow{2}{*}{$\begin{array}{c}\text { Average } \\
\text { bulk } \\
\text { milk } \\
\text { SCC }\end{array}$} & \multirow[b]{2}{*}{$\begin{array}{c}\text { Cows } \\
\text { with } \\
\mathrm{CM}(\%)\end{array}$} & \multirow[b]{2}{*}{$\begin{array}{c}\text { Cows } \\
\text { included } \\
\text { (no.) }\end{array}$} & \multirow[b]{2}{*}{$\begin{array}{c}\text { Cows } \\
\text { with } \\
\text { ML }(\%)\end{array}$} \\
\hline & & $\begin{array}{c}\text { Last year } \\
(\mathrm{kg} / \mathrm{yr} \\
\text { per cow })\end{array}$ & $\begin{array}{c}\text { Last year } \\
(\mathrm{kg} / \mathrm{d} \\
\text { per cow })\end{array}$ & $\begin{array}{c}\text { At dry-off } \\
(\mathrm{kg} / \mathrm{d} \\
\text { per cow })\end{array}$ & & & & \\
\hline Belgium & 701 & 10,436 & 28.0 & 14.0 & 142.0 & 1.2 & 7 & 14.3 \\
\hline Belgium & 208 & 10,845 & 30.2 & 13.0 & 156.7 & 1.5 & 50 & 44.0 \\
\hline Belgium & 165 & 8,685 & 28.0 & 15.0 & 161.3 & 1.3 & 7 & 42.9 \\
\hline Belgium & 164 & 8,933 & 24.6 & 12.0 & 264.3 & 1.9 & 26 & 19.2 \\
\hline Belgium & 102 & 9,816 & 24.0 & 6.0 & 259.7 & 5.0 & 19 & 0.0 \\
\hline Belgium & 85 & 9,568 & 29.0 & 15.0 & 163.3 & 1.3 & 13 & 38.5 \\
\hline Belgium & 77 & 10,448 & 28.0 & 13.0 & 170.7 & 1.5 & 13 & 0.0 \\
\hline Czech Republic & 650 & 12,000 & 35.0 & 26.0 & 246.7 & 3.6 & 63 & 0.0 \\
\hline Czech Republic & 483 & 11,400 & 34.0 & 22.0 & 250.0 & 4.6 & 42 & 47.6 \\
\hline Czech Republic & 360 & 8,900 & 29.0 & 14.0 & 227.7 & 3.2 & 1 & 0.0 \\
\hline Czech Republic & 337 & 7,800 & 22.0 & 5.0 & 222.7 & 3.0 & 35 & 0.0 \\
\hline Denmark & 565 & 10,885 & 29.8 & 25.0 & 171.3 & 4.9 & 69 & 40.6 \\
\hline Denmark & 530 & 11,293 & 31.0 & 30.0 & 229.3 & 2.5 & 55 & 63.6 \\
\hline Denmark & 260 & 9,865 & 27.0 & 24.0 & 235.7 & 3.1 & 23 & 30.4 \\
\hline France & 150 & 8,380 & 25.8 & 16.5 & 299.3 & 1.1 & 27 & 22.2 \\
\hline France & 109 & 8,386 & 26.5 & 10.0 & 266.7 & 2.0 & 4 & 0.0 \\
\hline France & 107 & 8,031 & 26.3 & 17.0 & 384.7 & 5.0 & 9 & 77.8 \\
\hline France & 97 & 10,700 & 26.6 & 15.0 & 176.7 & 4.8 & 7 & 28.6 \\
\hline France & 96 & 9,164 & 30.0 & 15.0 & 207.3 & 5.0 & 8 & 25.0 \\
\hline France & 92 & 9,600 & 30.5 & 16.0 & 320.7 & 1.2 & 5 & 40.0 \\
\hline France & 86 & 9,000 & 29.0 & 14.0 & 275.0 & 1.6 & 2 & 0.0 \\
\hline France & 82 & 8,583 & 28.1 & 18.0 & 386.0 & 1.8 & 8 & 62.5 \\
\hline France & 81 & 10,477 & 26.1 & 20.0 & 285.0 & 7.5 & 15 & 26.7 \\
\hline France & 76 & 9,944 & 32.6 & 18.0 & 319.3 & 2.0 & 5 & 0.0 \\
\hline France & 75 & 8,200 & 26.0 & 19.8 & 105.3 & 2.9 & 13 & 30.8 \\
\hline France & 73 & 8,028 & 26.3 & 16.0 & 252.7 & 2.0 & 6 & 16.7 \\
\hline France & 73 & 8,720 & 28.3 & 17.6 & 251.7 & 2.7 & 9 & 44.4 \\
\hline France & 71 & 8,250 & 27.0 & 18.6 & 230.0 & 1.0 & 8 & 25.0 \\
\hline France & 65 & 9,345 & 25.6 & 16.0 & 154.7 & 1.5 & 5 & 0.0 \\
\hline France & 60 & 8,335 & 27.0 & 15.0 & 227.3 & 5.0 & 13 & 30.8 \\
\hline France & 39 & 8,459 & 27.7 & 15.0 & 320.7 & 0.9 & 1 & 0.0 \\
\hline Germany & 690 & 8,695 & 25.0 & 12.5 & 226.3 & 6.0 & 135 & 7.4 \\
\hline Germany & 170 & 9,600 & 29.5 & 15.0 & 226.0 & 3.0 & 24 & 29.2 \\
\hline Italy & 435 & 10,300 & 33.5 & 23.1 & 232.7 & 2.1 & 67 & 26.9 \\
\hline Italy & 350 & 10,500 & 32.0 & 23.0 & 276.7 & 5.6 & 66 & 3.0 \\
\hline Italy & 200 & 9,500 & 31.0 & 18.0 & 236.3 & 1.8 & 10 & 20.0 \\
\hline Spain & 1,420 & 12,300 & 38.4 & 34.0 & 203.3 & 3.6 & 147 & 16.3 \\
\hline The Netherlands & 430 & 11,000 & 32.0 & 16.0 & 273.3 & 2.0 & 52 & 30.8 \\
\hline The Netherlands & 380 & 7,500 & 24.0 & 15.0 & 203.7 & 7.0 & 53 & 22.6 \\
\hline The Netherlands & 225 & 9,200 & 25.2 & 11.5 & 293.0 & 0.5 & 21 & 61.9 \\
\hline The Netherlands & 170 & 8,191 & 19.9 & 20.0 & 182.0 & 8.0 & 28 & 50.0 \\
\hline
\end{tabular}


registrations were incomplete for 4 cows), resulting in an average incidence of $24.5 \%$ for all included cows (Table 4). Table 1 shows that ML incidence differed between herds. In 10 herds no ML was observed, 16 herds had a ML incidence $\geq 20 \%$, and in 1 herd with only 9 cows enrolled, a ML incidence of $77.8 \%$ was observed. The average ML within-herd incidence was $30.6 \%$.

The distribution of ML observations over the different observation times is summarized in Table 4. The ML incidence was the highest from 30 to $34 \mathrm{~h}$ after DO

Table 2. Characteristics of the usual dry-off strategy of the 41 included herds

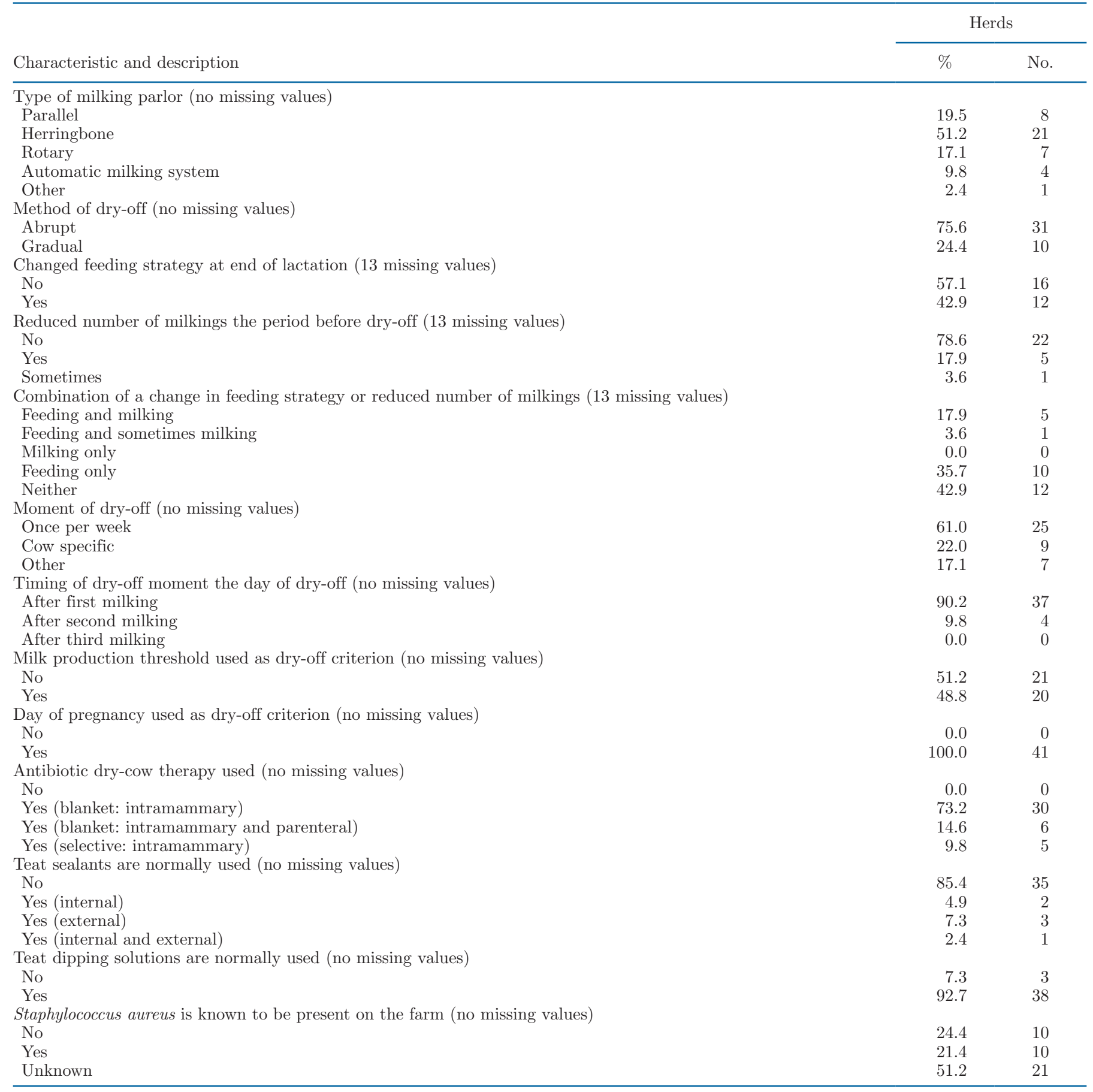


Table 3. Distribution of teat-end scores for the different teats $(\mathrm{n}=$ 4,700 teats)

\begin{tabular}{lcr}
\hline Quarter and teat end score & Percent & No. \\
\hline Left front & & \\
No ring & 39.7 & 466 \\
Smooth ring & 39.1 & 459 \\
Rough ring & 15.8 & 186 \\
Very rough ring & 5.5 & 64 \\
Unknown & 0 & 0 \\
Left rear & & \\
No ring & 46.8 & 550 \\
Smooth ring & 37.5 & 440 \\
Rough ring & 12.9 & 152 \\
Very rough ring & 2.7 & 32 \\
Unknown & 0.1 & 1 \\
Right front & & \\
No ring & 38.0 & 446 \\
Smooth ring & 39.7 & 467 \\
Rough ring & 17.3 & 203 \\
Very rough ring & 4.9 & 58 \\
Unknown & 0.1 & 1 \\
Right rear & & \\
No ring & 44.1 & 518 \\
Smooth ring & 39.3 & 462 \\
Rough ring & 13.1 & 154 \\
Very rough ring & 3.4 & 40 \\
Unknown & 0.1 & 1 \\
\hline
\end{tabular}

(16.1\%). Most cows were observed to leak milk for the first time between 20 and $24 \mathrm{~h}$ or 30 and $34 \mathrm{~h}$ after DO, although a substantial percentage were observed for the first time between 48 and $52 \mathrm{~h}$.

\section{Incidence of ML at Quarter Level}

Milk leakage was observed from 423 of 4,544 (9.3\%, $95 \%$ CI $=8.5-10.2)$ checked quarters at 1 or more observation times; ML information was missing from 140 quarters. Cows with complete ML observations (n $=246$ cows with 4 functional quarters observed 2 times on $3 \mathrm{~d}$ after DO) had on average 1.6 teats leaking milk $(95 \%$ CI $=1.5-1.7)$. Only 1 quarter was leaking in $54.9 \%$ of the cows with ML, 2 quarters in $32.5 \%, 3$ quarters in $8.1 \%$, and 4 quarters in $4.5 \%$. Rear quarters leaked significantly $(P<0.001)$ more frequently than front quarters; the odds ratio $(\mathbf{O R})$ was 4.7 (95\% CI = 3.5-6.3). The distribution of ML by quarter is shown in Table 5.

\section{Risk Factors for ML at Cow and Quarter Levels}

The final cow-level model contains 3 factors and 3 confounders (Table 6). Cows that were milked 2 or 3 times/d during lactation without reduction in frequency before DO had 11.0 and 14.3 times higher odds for ML, respectively, than cows that were reduced from 2 to 1 milking before DO.

Cows milked with an automatic milking system (AMS; 55 cows in 4 herds) had 33.9 times higher odds to leak milk than cows milked with a conventional milking system with a reduction from 2 to 1 milking/d before DO. Cows milked with an AMS did not leak milk more or less often after DO than cows milked with a conventional milking system that were milked 3 times/d and where the number of milkings was not reduced $(P=0.267)$.

The milk production $24 \mathrm{~h}$ before DO $>13 \mathrm{~L}$ and the ISCC $>200,000$ cells $/ \mathrm{mL}$ in the 3 mo before DO were factors that increased the odds of ML (Table 6). The only variable observed and analyzed at quarter level, the teat-end score, was not significantly associated with ML.

\section{CM and New IMI}

In total, CM was recorded in 109 out of 1,098 cows between day of DO and $30 \mathrm{~d}$ in lactation, resulting in an average incidence of $9.9 \%$ (Table 7 ). Cows with $\mathrm{CM}$ and information on all 4 quarters $(\mathrm{n}=101)$ had on average 1.4 quarters with $\mathrm{CM} ; 78.2 \%$ cows had 1 quarter with CM, $13.9 \%$ had 2 quarters, $1.0 \%$ had 3 quarters, and $6.9 \%$ had 4 quarters. The CM incidence per quarter was $2.8 \%$ for the right rear quarter, $3.2 \%$ for the right front quarter, $3.5 \%$ for the left rear quarter and $3.2 \%$ for the left front quarter. No significant differences in CM were seen between rear and front quarters or between left and right quarters. Clinical mastitis was recorded in 22 cows during the dry period and in 95 cows in the first $30 \mathrm{~d}$ in lactation, resulting in an average incidence of $1.9 \%$ and $8.7 \%$, respectively.

A rise in ISCC was present in 138 out of 805 eligible cows, which resulted in an average ISCC rise incidence of $17.1 \%$. New IMI were present in 180 out of 806 eli-

Table 4. Milk leakage (ML) observations at cow level over the 3 observation times $(\mathrm{n}=1,171$ cows)

\begin{tabular}{lccc}
\hline $\begin{array}{l}\text { Hours } \\
\text { after dry-off }\end{array}$ & $\begin{array}{c}\text { ML incidence } \\
\text { \% of all cows) }\end{array}$ & $\begin{array}{c}\text { 95\% CI } \\
\text { (\% of all cows) }\end{array}$ & $\begin{array}{c}\text { First ML observation } \\
\text { (\% of 287 cows with ML) }\end{array}$ \\
\hline $20-24$ & 10.8 & $9.0-12.7$ & 43.9 \\
$30-34$ & 16.1 & $14.1-18.4$ & 39.0 \\
$48-52$ & 9.1 & $7.5-10.8$ & 17.1 \\
$20-52$ & 24.5 & $22.0-27.0$ & - \\
\hline
\end{tabular}


Table 5. Milk leakage (ML) incidence by quarter

\begin{tabular}{lccc}
\hline Quarter & No. & $\begin{array}{c}\text { ML incidence } \\
(\%)\end{array}$ & $\begin{array}{c}95 \% \text { CI } \\
(\%)\end{array}$ \\
\hline Left front & 1,135 & 4.4 & $3.2-5.6$ \\
Right front & 1,132 & 6.1 & $4.7-7.5$ \\
Left rear & 1,138 & 14.1 & $12.0-16.1$ \\
Right rear & 1,139 & 12.6 & $10.7-14.6$ \\
\hline
\end{tabular}

gible cows (Table 7). The average new IMI incidence was estimated to be $22.3 \%$.

\section{Association Between ML and CM in the First 30 d in Lactation}

The association between ML and CM in the first 30 $\mathrm{d}$ in lactation was investigated using 2 multivariable models, 1 at quarter level and 1 at cow level (Table 8). Quarters that experienced ML tended to have 2.0 times higher odds of developing CM than quarters without ML. Teat-end score was not significantly associated with $\mathrm{CM}$ in the first $30 \mathrm{~d}$ in lactation.

At cow level, no significant association between ML and $\mathrm{CM}$ in the first $30 \mathrm{~d}$ in lactation was found. The only variable associated with $\mathrm{CM}$ at cow level in the first $30 \mathrm{~d}$ in lactation was the average ISCC in the last 3 mo before DO (Table 8 ).

\section{Association Between ML and New IMI During Dry Period and the First $30 \mathrm{~d}$ in Lactation}

The association between ML and new IMI during the dry period and in the first $30 \mathrm{~d}$ in lactation was investigated using a multivariable model at cow level (Table 9 ). When ML was forced into the final model, it tended to be associated with new IMI; cows with ML had 1.5 times higher odds of new IMI during the dry period and the first $30 \mathrm{~d}$ in lactation than cows without ML.

The final model for new IMI included 3 variables and 3 confounders (Table 9). Cows with a 305-d lactation yield $>10,294 \mathrm{~L}$ had higher odds of new IMI than cows with a yield $\leq 8,521 \mathrm{~L}$. Cows with a milk production $24 \mathrm{~h}$ before $\mathrm{DO}<13$ and $>21 \mathrm{~L}$ had 1.7 and 1.6-higher odds on new IMI, respectively, when compared with cows producing 13 to $21 \mathrm{~L}$ in the last $24 \mathrm{~h}$ before DO. In addition, cows with a high average ISCC in the last 3 mo before DO (i.e., $>100,000$ cells $/ \mathrm{mL}$ ) had higher odds of new IMI than cows $<100,000$ cells $/ \mathrm{mL}$.

Table 6. Results of mixed-effects logistic regression analysis ${ }^{1}$ of milk leakage $(\mathrm{n}=1,143$ cows)

\begin{tabular}{|c|c|c|c|c|}
\hline Parameter $^{2}$ & $\begin{array}{l}\text { Coefficient } \\
\quad(\mathrm{SE})\end{array}$ & $P$-value & $\mathrm{OR}^{4}(95 \%-\mathrm{CI})$ & No. \\
\hline Intercept & $-5.16(0.81)$ & & & \\
\hline \multicolumn{5}{|c|}{ Reduction of milkings } \\
\hline $2 \rightarrow 2$ & $2.40(0.60)$ & $<0.0001$ & $11.03(3.43-35.46)$ & 517 \\
\hline $3 \rightarrow 2$ & $2.25(0.83)$ & 0.007 & $9.45(1.85-48.22)$ & 251 \\
\hline $3 \rightarrow 3$ & $2.66(0.74)$ & $<0.0001$ & $14.28(3.32-61.43)$ & 143 \\
\hline \multicolumn{5}{|c|}{ Production $24 \mathrm{~h}$ before dry-off (L) } \\
\hline$<13$ & Baseline & & & 359 \\
\hline $13-21$ & $0.83(0.22)$ & $<0.0001$ & $2.28(1.48-3.53)$ & 461 \\
\hline$>21$ & $1.13(0.28)$ & $<0.0001$ & $3.09(1.79-5.30)$ & 323 \\
\hline \multicolumn{5}{|c|}{ Average ISCC 3 mo before dry-off $(\times 1,000$ cells $/ \mathrm{mL})$} \\
\hline$<100$ & Baseline & & & 584 \\
\hline $100-200$ & $0.11(0.21)$ & 0.581 & $1.12(0.75-1.68)$ & 268 \\
\hline$\geq 200$ & $0.50(0.19)$ & 0.009 & $1.65(1.13-2.41)$ & 291 \\
\hline 2 Gradual & Baseline & & & 198 \\
\hline 1 Abrupt & $0.49(0.55)$ & 0.369 & $1.64(0.56-4.82)$ & 945 \\
\hline \multicolumn{5}{|c|}{ Use of a teat dipping solution after milking } \\
\hline 1 Yes & Baseline & & & 1,127 \\
\hline $2 \mathrm{No}$ & $1.05(0.81)$ & 0.193 & $2.86(0.59-13.88)$ & 16 \\
\hline
\end{tabular}

${ }^{1}$ Random farm effect was estimated at 0.56 ( $\mathrm{SE}=0.23$; logit scale); intraclass correlation coefficient was $0.15(95 \% \mathrm{CI}=0.07-0.28)$.

${ }^{2}$ ISCC = individual somatic cell count; confounders = presence of Staphylococcus aureus on the farm, method of dry-off, and use of a teat dipping solution after milking.

${ }^{3} \mathrm{n}=55$. Due to the automatic milking system (AMS), the number of milkings that was set in the AMS for the cow was not recorded. ${ }^{4} \mathrm{OR}=$ odds ratio. 
Table 7. Descriptive statistics of observed new IMI

\begin{tabular}{|c|c|c|c|c|}
\hline \multirow[b]{2}{*}{ IMI indicators $^{1}$} & \multicolumn{2}{|c|}{ Cow level } & \multicolumn{2}{|c|}{ Quarter level $^{2}$} \\
\hline & $\begin{array}{c}\text { Cows } \\
\text { (no. eligible) }\end{array}$ & $\begin{array}{l}\text { Incidence } \\
(95 \% \text { CI })\end{array}$ & $\begin{array}{c}\text { Quarters } \\
\text { (no. eligible) }\end{array}$ & $\begin{array}{l}\text { Incidence } \\
(95 \% \text { CI })\end{array}$ \\
\hline CM from dry-off to calving & $22(1,139)$ & $1.9(1.1-2.7)$ & $26(4,372)$ & $0.6(0.4-0.8)$ \\
\hline $\mathrm{CM}$ within the first $30 \mathrm{~d}$ in lactation & $95(1,095)$ & $8.7(7.0-10.4)$ & $118(4,360)$ & $2.7(2.2-3.2)$ \\
\hline Rise in ISCC & $138(805)^{3}$ & $17.1(14.5-19.8)$ & \multicolumn{2}{|c|}{ NA } \\
\hline
\end{tabular}

${ }^{1} \mathrm{CM}=$ clinical mastitis (note that 8 cows and 6 quarters developed mastitis in both periods); ISCC = individual somatic cell count.

${ }^{2} \mathrm{NA}=$ not available.

${ }^{3}$ ISCC information was missing for 1 of the 806 eligible cows.

${ }^{4}$ Increase of ISCC from $<200,000$ cells $/ \mathrm{mL}$ at the last record before dry-off to $\geq 200,000$ cells $/ \mathrm{mL}$ at the first record after calving, presence of $\mathrm{CM}$ in 1 or multiple quarters from dry-off up to $30 \mathrm{~d}$ after calving, or both.

\section{DISCUSSION}

Drying-off in modern dairy herds has become a complex and challenging process due to the increase of milk production (Stefanon et al., 2002; Zobel et al., 2015). The amount of milk in the udder at the end of lactation and the method of drying-off cows may influence the incidence of ML immediately after DO (Tucker at al., 2009; Zobel et al., 2013). As few peer-reviewed papers have been published on ML after DO, the objective of this study was to investigate the current incidence of cows leaking milk during the first $2 \mathrm{~d}$ after DO in commercial dairy herds around Europe. In addition, the relation between possible risk factors and the incidence of ML as well as the relation between the presence of ML and the occurrence of CM and new IMI across the dry period and after calving were investigated.

The average ML incidence at cow level 20 to $52 \mathrm{~h}$ after DO was $24.5 \%$ and differed between the partici- pating herds. This is the first study in which the ML incidence was studied with a high number of cows $(\mathrm{n}=$ $1,142)$ at multiple commercial herds $(\mathrm{n}=41)$ in multiple countries in Europe $(\mathrm{n}=8)$ with different DO strategies. Other studies on ML occurrence included lower numbers of animals and herds. Schukken et al. (1993) reported 30\% with ML the week after DO in cows from 1 Dutch experimental herd, whereas Tucker et al. (2009) reported $14 \%$ with ML on d 2 after DO in lowproductive cows and $42 \%$ with ML in high-productive cows from a 64-cow experimental herd in New Zealand. Zobel et al. (2013) reported $75 \%$ with ML after abrupt DO and $27 \%$ after gradual DO in cows in a 24 -cow experimental herd in Canada (average milk production at the last milking was 14.1 and $10.9 \mathrm{~kg}$, respectively). In Europe, Bach et al. (2015) found 12\% ML after abrupt DO in 100 cows from 1 commercial herd, whereas Bertulat et al. (2017) found 22\% ML in 119 cows from 16 commercial herds. Recently, Hop et al. (2019) reported

Table 8. Results of mixed-effects logistic regression analysis of clinical mastitis in the first $30 \mathrm{~d}$ in lactation at quarter level and at cow level

\begin{tabular}{|c|c|c|c|c|c|c|}
\hline Parameter & Coefficient & $\mathrm{SE}$ & $P$-value & $\mathrm{OR}^{1}$ & $95 \% \mathrm{CI}$ & No. \\
\hline Intercept & -5.40 & 0.37 & & & & 4,195 \\
\hline \multicolumn{7}{|l|}{ Milk leakage } \\
\hline Yes & 0.67 & 0.38 & 0.080 & 1.95 & $0.92-4.12$ & 385 \\
\hline \multicolumn{7}{|l|}{ Cow level model ${ }^{3}$} \\
\hline \multicolumn{6}{|l|}{ Average ISCC in 3 mo before dry-off $(\times 1,000$ cells $/ \mathrm{mL})$} & 1,078 \\
\hline $100-200$ & 0.57 & 0.28 & 0.044 & 1.76 & $1.02-3.05$ & 253 \\
\hline$\geq 200$ & 0.92 & 0.26 & $<0.0001$ & 2.51 & $1.51-4.16$ & 264 \\
\hline \multicolumn{7}{|l|}{ Milk leakage } \\
\hline No & Baseline & & & & & 819 \\
\hline Yes & -0.01 & 0.22 & 0.966 & 0.99 & $0.58-1.68$ & 259 \\
\hline
\end{tabular}

${ }^{1} \mathrm{OR}=$ odds ratio.

${ }^{2}$ Random farm effect: 0.37 ( $\mathrm{SE}=0.28$; logit scale) and intraclass correlation coefficient: 0.05 (95\% CI $\left.=0.01-0.18\right)$, random cow effect: 4.15 (SE $=1.00$; logit scale) and intraclass correlation coefficient: $0.58(95 \% \mathrm{CI}=0.46-0.68)$.

${ }^{3}$ Random farm effect: 0.15 ( $\mathrm{SE}=0.16$; logit scale) and intraclass correlation coefficient: 0.04 (95\% CI: 0.01-0.26). 
$11 \% \mathrm{ML}$ in cows that were not treated with a dry-cow treatment $(\mathrm{n}=298)$ and almost $15 \%$ ML in cows that were treated with an intramammary dry-cow therapy $(\mathrm{n}=304)$ in 80 commercial herds across Europe. Other non-European studies reported an ML incidence within $2 \mathrm{~d}$ after DO when observing 2,166 cows of 24, 31, 26, and $50 \%$ in Mexico, Brazil, United States, and Russia, respectively (De Prado-Taranilla et al., 2018).

In the different peer-reviewed studies, the methodology of measuring ML differed and was not standardized and therefore is not fully comparable. In our study, the cows were observed at quarter level for 2 periods of 30 $\mathrm{s}$ at 3 different visits, whereas in Zobel et al. (2013), the cows were observed every 20 min during $2 \mathrm{~h}$ after 2 expected milking times after DO. This more intensive observation, could explain the difference in the incidence of ML obtained between our study and the study of Zobel et al. In the study of Tucker et al. (2009), each cow was observed on d 1, 2, 3, 4, and 8 after DO, and in the study of Schukken et al. (1993), each cow was observed daily during the first week after DO. None of the studies described the observation time.

With regard to the timing of ML, $43.9 \%$ of the cows leaking milk did so for the first time at the visit 20 to $24 \mathrm{~h}$ after DO. This could be expected as the intramammary pressure rises after DO (Bach et al., 2015; Bertulat et al., 2017), and the cow would be expecting to be milked at this time point. However, in our study, $39.0 \%$ of the cows leaking milk did so for the first time at the 30 to $34 \mathrm{~h}$ after DO observation time. In our experience these findings are in line with other studies performed outside Europe (Brazil, Mexico, Russia, and Saudi Arabia) where ML was also observed for the first time at the same time points after DO (A. I. De Prado-

Table 9. Results of mixed-effects logistic regression analysis of new $\mathrm{IMI}^{1}$

\begin{tabular}{|c|c|c|c|c|}
\hline Parameter $^{2}$ & Coefficient (SE) & $P$-value & $\mathrm{OR}^{3}(95 \% \mathrm{CI})$ & No. \\
\hline Intercept & $-2.36(0.35)$ & & & 788 \\
\hline \multicolumn{5}{|c|}{ Current lactation yield (L) } \\
\hline$\leq 8,521$ & Baseline & & & 206 \\
\hline$\overline{8}, 521-10,294$ & $0.46(0.29)$ & 0.108 & $1.58(0.90-2.77)$ & 193 \\
\hline $10,294-12,231$ & $1.02(0.29)$ & 0.001 & $2.76(1.55-4.91)$ & 190 \\
\hline$>12,231$ & $0.62(0.34)$ & 0.069 & $1.86(0.95-3.64)$ & 199 \\
\hline \multicolumn{5}{|c|}{ Production 24 h before dry-off (L) } \\
\hline$<13$ & $0.59(0.24)$ & 0.014 & $1.80(1.13-2.89)$ & 203 \\
\hline $13-21$ & Baseline & & & 333 \\
\hline$>21$ & $0.41(0.25)$ & 0.098 & $1.51(0.93-2.46)$ & 252 \\
\hline \multicolumn{5}{|c|}{ Average ISCC in 3 mo before dry-off ${ }^{4}(\times 1,000$ cells $/ \mathrm{mL})$} \\
\hline$<100$ & Baseline & & & 554 \\
\hline $100-200$ & $0.57(0.21)$ & 0.007 & $1.77(1.17-2.67)$ & 187 \\
\hline$\geq 200$ & $0.66(0.36)$ & 0.066 & $1.93(0.96-3.90)$ & 47 \\
\hline \multicolumn{5}{|l|}{ Milk leakage } \\
\hline No & Baseline & & & 602 \\
\hline Yes & $0.40(0.22)$ & 0.076 & $1.49(0.96-2.31)$ & 186 \\
\hline \multicolumn{5}{|l|}{ Parity } \\
\hline 1 & $0.68(0.49)$ & 0.166 & $1.97(0.75-5.14)$ & 412 \\
\hline 2 & $0.78(0.48)$ & 0.109 & $2.17(0.84-5.62)$ & 225 \\
\hline 3 & $0.94(0.52)$ & 0.071 & $2.56(0.92-7.09)$ & 84 \\
\hline 4 & Baseline & & & 39 \\
\hline 5 or higher & $1.34(0.63)$ & 0.032 & $3.84(1.12-13.10)$ & 28 \\
\hline \multicolumn{5}{|c|}{ Average percentage of clinical mastitis on the farm per month } \\
\hline$\leq 2.1$ & $0.00(0.35)$ & 0.999 & $1.00(0.51-1.98)$ & 217 \\
\hline$\overline{2} .1-3.6$ & $0.69(0.34)$ & 0.040 & $2.00(1.03-3.88)$ & 272 \\
\hline $3.6-5.6$ & Baseline & & & 141 \\
\hline$>5.6$ & $0.16(0.45)$ & 0.731 & $1.17(0.48-2.84)$ & 158 \\
\hline \multicolumn{5}{|l|}{ Country } \\
\hline Belgium & $1.07(0.47)$ & 0.023 & $2.91(1.16-7.31)$ & 96 \\
\hline Czech Republic & $0.37(0.54)$ & 0.497 & $1.44(0.50-4.18)$ & 89 \\
\hline Denmark & $0.54(0.53)$ & 0.306 & $1.72(0.61-4.83)$ & 101 \\
\hline France & $1.14(0.46)$ & 0.013 & $3.12(1.28-7.64)$ & 79 \\
\hline Germany & $1.10(0.44)$ & 0.013 & $3.00(1.26-7.16)$ & 103 \\
\hline Italy & $1.08(0.49)$ & 0.026 & $2.95(1.14-7.65)$ & 87 \\
\hline The Netherlands & Baseline & & & 109 \\
\hline Spain & $0.34(0.59)$ & 0.563 & $1.40(0.44-4.45)$ & 124 \\
\hline
\end{tabular}

${ }^{1}$ Random farm effect: 0.00 ( $\mathrm{SE}=0.00$; logit scale) and intraclass correlation coefficient: $0.00(95 \% \mathrm{CI}=0.00-1.00)$.

${ }^{2}$ Confounders $=$ parity, average percentage of clinical mastitis on the farm per month, and country.

${ }^{3} \mathrm{OR}=$ odds ratio.

${ }^{4}$ ISCC $=$ individual somatic cell count. The most recent ISCC was never above 200,000 cells/mL as this was an inclusion criterion for this analysis. Therefore, this group is relatively small in this analysis $(\mathrm{n}=47)$, and the power to detect a significant association is lower. 
Taranilla, unpublished data). We hypothesize that this may be related to the time the udder is able to keep the high pressure due to the huge amount of cisternal milk without affecting the sphincter canal. Once the udder pressure exceeds a certain threshold, ML may appear.

Because we did not observe the occurrence of ML continuously, but only twice for $30 \mathrm{~s}$ at 3 visits, it can be expected that we missed some cows that were leaking milk between observation times. In the study of Zobel et al. (2013), all teats were sealed internal and externally, whereas in our study the use of teat sealers was forbidden; hence, the actual ML incidence might be higher than the $24.5 \%$ that we observed in this study.

At quarter level, rear quarters leaked milk more often than front quarters. This may be explained by an enlarged pressure on the rear quarters as the rear quarters produce more milk (Weiss et al., 2004; Tancin et al., 2006). Unexpectedly, the teat-end score was not associated with the presence of ML, although this association was demonstrated in other studies (Persson Waller et al., 2003; Klaas et al., 2005; Rovai et al., 2007). We hypothesize that the incidence of ML in this study was more related to the high pressure in the udder and the capacity of the sphincter to support this pressure than with the teat-end condition. Although the percentage of poor-condition teat ends is only around the $20 \%$, the number of teat ends checked in this study was comparable (Klass et al., 2005; cows $=1,557$ ) or greater than the number of teats involved in other studies (Persson Waller et al., 2003; cows $=198$, quarters $=792$ ) where the association was proven.

The reduction in the number of milkings in the final week of lactation was highly related to the presence of ML. Our results show that when a farmer chooses not to reduce the number of milkings, the risk that a cow will leak milk is higher than when the number of milkings is reduced from twice to once per day. The risk of ML is even higher for cows that are milked more than 3 times/d during lactation (i.e., 3 times or with an AMS where cows can choose when they want to be milked); hence, reducing milk production before DO helps to reduce the ML incidence. Our findings are consistent with Zobel et al. (2013), who observed that an abrupt DO strategy results in more cows leaking milk after DO compared with a gradual DO strategy. However, Tucker at al. (2009) reported that the reduction from 2 to 1 milking $8 \mathrm{~d}$ before DO, lowered milk production by $20 \%$ but did not result in less ML. Also, results from Gott et al. (2016) showed that the ML incidence did not differ between milk cessation groups, and that cows milked once daily in the final week of lactation tended to have higher odds of being observed with ML after DO than cows that were dried off abruptly. The diverging effect of the different herd strategies for the reduction in milkings on the incidence of ML underlines, therefore, the importance of developing a herd-specific DO protocol to reduce ML after DO.

We also found that cows with higher milk production before DO had higher odds of leaking milk, which is consistent with the findings of Zobel et al. (2013), who observed a lower ML incidence in cows that were gradually dried off compared with cows that were dried off abruptly (gradual DO: $\mathrm{ML}=27 \%$, milk production $=10.9 \mathrm{~kg}$.; abrupt DO: $\mathrm{ML}=75 \%$, milk production $=$ $14.1 \mathrm{~kg}$ ) Similarly, Hop et al. (2019) found that cows with a daily milk yield of $>18 \mathrm{~kg}$ on the day before DO showed increased odds of ML $(\mathrm{OR}=3.19)$ compared with cows with a daily milk yield $\geq 13$ but $\leq 18 \mathrm{~kg}$ on the day before DO. In contrast, Gott et al. (2016) reported that the ML incidence after DO was lower in abrupt-cessation cows than in cows milked once per day at the end of lactation (8.9 vs. $16.1 \%$, respectively) although this difference was not significant.

Although the milk production before DO was associated with ML, the 305-d milk production was not significantly associated with ML, at least at the level of milk production achieved by the herds in this study. This suggests that intensive selection for increasing milk production does not necessarily have to result in a higher ML incidence after DO. In contrast, this high milk production imposes stress on the bovine udder, and immunity may be reduced, leading to more SCC in their milk (Alhussien and Dang, 2018). According to previous studies, ML is not exclusively a characteristic of high-producing cows. Klaas et al. (2005), for example, found that lower-yielding primiparous cows with greater peak milk flow rates in 15 commercial German herds were at higher risk of leaking milk than high-yielding cows. Additionally, multiparous cows with short teats, inverted teat ends, and teat-canal protrusions that may have less sphincter muscle tone have increased risk of ML. It has also been observed that milk flow rates were higher in quarters leaking milk than in other quarters (Persson Waller et al., 2003; Rovai et al., 2007). Hence, if high-yielding cows are managed and dried off with a lower milk production of the final day of lactation, most ML after DO may be prevented. Although we observed a high incidence of ML in farms with AMS, we cannot form any conclusion due to the low number of cows milked by this system. Automatic milking system farms and cows had relatively low milk production; however, Person Waller et al. (2003) showed that ML in AMS occurred more than in conventional milking systems. Hence, studies to identify if AMS may a risk for ML are needed.

Our results show that an average ISCC in the last 3 mo before DO of $>200,000$ cells $/ \mathrm{mL}$ is associated with higher odds of leaking milk $(\mathrm{OR}=1.65)$. We hypothe- 
sized that cows with a higher parity could be associated with having a poorer teat-end condition scores and, therefore, have a higher risk of ML and a higher ISCC. However, in our study, parity and teat-end condition score were not associated with ML. Consequently, our hypothesis was not supported. Because the studies on ML are limited, there is no literature on the association between ML and ISCC.

We found that farmers apply different DO strategies. Interestingly, we noticed that the changes of the feed ration or feed restriction before last milking aiming to lower milk production before DO were not always considered gradual dry-off management. Many farmers considered reducing the number of milkings as a gradual DO strategy but not the change in feeding management. The number of herds in different countries adjusting feed rations to reduce milk production before DO has been studied by different authors (Bertulat et al., 2015; Fujiwara et al., 2018). Restricting feed intake may cause serious welfare problems and metabolic disturbances (Odensten et al., 2005, 2007; Tucker et al., 2009) and may affect economical return (Steeneveld et al., 2019).

Milk leakage was not associated with CM during $30 \mathrm{~d}$ postcalving at cow level, but a trend toward a significant association showed up with new IMI in general. The trend was present when ML was forced into a multivariable model with other factors associated with IMI. At quarter level, again a trend toward significance $(P=0.07)$ was found for the association between ML and CM postcalving. Quarters with ML tended to have 2.0 times higher odds to develop CM compared with quarters not leaking milk.

Similarly, cows with ML tended to have 1.5 times higher odds of new IMI compared with cows without ML. The association was not significant, possibly because the ISCC data were not corrected for the different ISCC test day and recording systems across countries and for the timing of milk sampling in relation to the DO moment or day of calving.

An association between udder health characteristics and ML was found in previous studies. For example, Schukken et al. (1993) showed that cows leaking milk after DO were 4 times more likely to develop CM and had 6.1 times higher risk of developing a new IMI with a major pathogen during the dry period than cows that did not leak milk. It was concluded that ML was strongly associated with CM and new IMI with major pathogens in the dry period. Gott et al. (2016) showed that quarters observed with ML at least once after DO in primiparous cows had 28.9 times higher odds of new IMI at calving than quarters that were not observed leaking milk after DO. Milk leakage is indicative of an open teat canal, and thus, bacteria can penetrate the teat canal and colonize the mammary gland (Cousins et al., 1980). In this way, the percentage of cows with ML was associated with an increased incidence rate of Escherichia coli and Staphylococcus aureus CM in herds with low SCC (Schukken et al., 1990, 1991).

It can be hypothesized that milk leaked in the bedding of cubicles may enhance the nutrient environment for microorganism in the bedding and, consequently, increase the environmental exposure of open teat canals. Therefore, the risk of udder infections in association with ML increases when the hygiene in the cows' environment, especially in the bedding, is poor. New IMI during the dry period and early lactation could potentially be minimized by reducing ML. As high milk production at DO is related to an increased risk of ML (Zobel et al., 2013) and to an increased risk of new IMI (Dingwell et al., 2004; Rajala-Schultz et al., 2005; Gott et al., 2016), strategies to reduce milk production at DO are important to reduce the risk for ML and new IMI. Recently, it has been shown that prolactin inhibitors, such as cabergoline, decreased milk production at $\mathrm{DO}$, reduced $\mathrm{ML}$, and hastened mammary gland involution (Bach et al., 2015, Boutinaud et al., 2016, 2017; Bertulat et al., 2017). Particularly, Hop et al. (2019) demonstrated that 1 intramuscular injection of cabergoline at drying-off significantly reduced the risk of new IMI by major pathogens across the dry period and postcalving compared with cows that were treated with a placebo. Safe strategies to reduce ML incidence and consequently the risk of acquiring new IMI during the dry period and at calving seem to be a possible solution to reduce the antimicrobial usage. This would contribute to a strategic plan to reduce antibiotic usages for udder infections and to follow the Global Action Plan on Antimicrobial Resistance (WHO, 2015).

\section{CONCLUSIONS}

The modern dairy farmers have to dry off highproductive cows. The objective of this study was to investigate the incidence of ML after DO and related risk factors. The association between ML and new IMI at calving was also evaluated. A total of 1,175 dairy cows from 41 herds in 8 European countries were included in the study. Results obtained showed that $24.5 \%$ of the cows leaked milk within $52 \mathrm{~h}$ after DO. Not reducing the number of milkings before DO, high milk production $24 \mathrm{~h}$ before DO, and high average ISCC before DO were risk factors for ML. Quarters with ML tended to have 2.0 times higher odds of developing CM until $30 \mathrm{~d}$ after calving compared with quarters that did not leak milk. Similarly, cows with ML tended to have 1.5 times higher odds of new IMI compared with cows without ML. Dry-off methods that reduce ML and that do not 
negatively affect the welfare and health of the animals or the profitability of the farmers should be further investigated. The reduction of ML and, consequently, new IMI during the dry period and at calving may contribute to a reduction of antimicrobial usage and, consequently, to less antibiotic resistance.

\section{ACKNOWLEDGMENTS}

The authors thank the staff of the 41 dairy herds involved in the research for taking care of the cows and providing the information required by the investigators. We also are grateful to the technical staff of Ceva Santé Animale (Libourne, France) for their assistance with monitoring the data: Stephane Folch and Nathalie Menudier (France), Annette Forro (Germany), Giorgio Valla (Italy), Geoffrey Ackaert (Belgium), Antonio Jiménez (Spain), Kjeld Lynge Madsen (Denmark), and Tomas Palenik (Czech Republic). The authors gratefully acknowledge the financial support of Ceva Santé Animale to conduct this study. In addition, we thank the reviewers whose suggestions helped to improve and clarify this manuscript. The authors have not stated any conflicts of interest.

\section{REFERENCES}

Alhussien, M. N., and A. K. Dang. 2018. Milk somatic cells, factors influencing their release, future prospects, and practical utility in dairy animals: An overview. Vet. World 11:562-577. https://doi .org/10.14202/vetworld.2018.562-577.

Bach, A., A. De-Prado, and A. Aris. 2015. Short communication: The effects of cabergoline administration at dry-off of lactating cows on udder engorgement, milk leakages, and lying behavior. J. Dairy Sci. 98:7097-7101. https://doi.org/10.3168/jds.2015-9751.

Bachman, K. C., and M. L. Schairer. 2003. Invited review: Bovine studies on optimal lengths of dry periods. J. Dairy Sci. 86:30273037. https://doi.org/10.3168/jds.S0022-0302(03)73902-2.

Bertulat, S., C. Fischer-Tenhagen, and W. Heuwieser. 2015. A survey of drying-off practices on commercial dairy farms in northern Germany and a comparison to science-based recommendations. Vet. Rec. Open 2:e000068. https://doi.org/10.1136/vetreco-2014 -000068 .

Bertulat, S., N. Isaka, A. de Prado, A. Lopez, T. Hetreau, and W. Heuwieser. 2017. Effect of a single injection of cabergoline at dry off on udder characteristics in high-yielding dairy cows. J. Dairy Sci. 100:3220-3232. https://doi.org/10.3168/jds.2015-10220.

Boutinaud, M., N. Isaka, E. Gandemer, P. Lamberton, S. Wiart, A. I. De Prado Taranilla, L. M. Sordillo, and V. Lollivier. 2017. Inhibiting prolactin by cabergoline accelerates mammary gland remodeling during the early dry period in dairy cows. J. Dairy Sci. 100:9787-9798. https://doi.org/10.3168/jds.2017-12783.

Boutinaud, M., N. Isaka, V. Lollivier, F. Dessauge, E. Gandemer, P. Lamberton, A. I. De Prado Taranilla, A. Deflandre, and L. M. Sordillo. 2016. Cabergoline inhibits prolactin secretion and accelerates involution in dairy cows after dry-off. J. Dairy Sci. 99:5707-5718. https://doi.org/10.3168/jds.2015-10782.

Capuco, A. V., and R. M. Akers. 1999. Mammary involution in dairy animals. J. Mammary Gland Biol. Neoplasia 4:137-144. https:// doi.org/10.1023/A:1018769022990.

Choudhary, R. K. 2014. Mammary stem cells: Expansion and animal productivity. J. Anim. Sci. Biotechnol. 5:36. https://doi.org/10 .1186/2049-1891-5-36.
Collier, R. J., E. L. Annen-Dawson, and A. Pezeshki. 2012. Effects of continuous lactation and short dry periods on mammary function and animal health. Animal 6:403-414. https://doi.org/10.1017/ S1751731111002461.

Cousins, C. L., T. M. Higgs, E. R. Jackson, F. K. Neave, and F. H. Dodd. 1980. Susceptibility of the bovine udder to bacterial infection in the dry period. J. Dairy Res. 47:11-18. https://doi.org/10 $.1017 /$ S0022029900020823.

De Prado-Taranilla, A. I., M. Holstege, A. Bach, Y. H. Schukken, and A. Velthuis. 2018. Distribution of prevalence of cows leaking milk after dry-off in different countries. J. Dairy Sci. 101(Suppl. 2):70. (Abstr.)

Dingwell, R. T., D. F. Kelton, K. E. Leslie, and V. L. Edge. 2001. Deciding to dry-off: Does level of production matter? Pages 69-79 in Proc. Annual Meeting of National Mastitis Council. NMC, Reno, NV.

Dingwell, R. T., K. E. Leslie, Y. H. Schukken, J. M. Sargeant, L. L. Timms, T. F. Duffield, G. P. Keefe, D. F. Kelton, K. D. Lissemore, and J. Conklin. 2004. Association of cow and quarter-level factors at drying-off with new intramammary infections during the dry period. Prev. Vet. Med. 63:75-89.

Fujiwara, M, M. J. Haskell, A. I. Macrae, and K. M. D. Rutherford. 2018. Survey of dry cow management on UK commercial dairy farms. Vet. Rec. 183:297.

Gott, P. N., P. J. Rajala-Schultz, G. M. Schuenemann, K. L. Proudfoot, and J. S. Hogan. 2016. Intramammary infections and milk leakage following gradual or abrupt cessation of milking. J. Dairy Sci. 99:4005-4017. https://doi.org/10.3168/jds.2015-10348.

Hop, G. E., A. I. de Prado-Taranilla, N. Isaka, M. Ocak, J. Bertet, K. Supré, A. Velthuis, Y. H. Schukken, and A. Deflandre. 2019. Efficacy of cabergoline in a double-blind randomized clinical trial on milk leakage reduction at drying-off and new intramammary infections across the dry period and postcalving. J. Dairy Sci. 102:11670-11680. https://doi.org/10.3168/jds.2019-16281.

Huxley, J. N., M. J. Green, L. E. Green, and A. J. Bradley. 2002. Evaluation of the efficacy of an internal teat sealer during the dry period. J. Dairy Sci. 85:551-561. https://doi.org/10.3168/jds .S0022-0302(02)74108-8.

Ingvartsen, K. L., R. J. Dewhurst, and N. C. Friggens. 2003. On the relationship between lactational performance and health: Is it yield or metabolic imbalance that cause production diseases in dairy cattle? A position paper. Livest. Prod. Sci. 83:277-308. https:// doi.org/10.1016/S0301-6226(03)00110-6.

Klaas, I. C., C. Enevoldsen, A. K. Ersbøll, and U. Tölle. 2005. Cow-related risk factors for milk leakage. J. Dairy Sci. 88:128-136. https: //doi.org/10.3168/jds.S0022-0302(05)72670-9.

Neave, F. K., F. H. Dodd, and E. Henriques. 1950. Udder Infections in the Dry Period. J. Dairy Res. 17:37-49. https://doi.org/10.1017/ S0022029900005628.

NMC (National Mastitis Council). 2006. NMC Factsheet-Dry Cow Therapy. National Mastitis Council, New Prague, MN.

Odensten, M. O., Y. Chilliard, and K. Holtenius. 2005. Effects of two different feeding strategies during dry-off on metabolism in highyielding dairy cows. J. Dairy Sci. 88:2072-2082. https://doi.org/10 .3168/jds.S0022-0302(05)72884-8.

Odensten, M. O., K. Holtenius, and K. P. Waller. 2007. Effects of two different feeding strategies during dry-off on certain health aspects of dairy cows. J. Dairy Sci. 90:898-907. https://doi.org/10.3168/ jds.S0022-0302(07)71573-4.

Ollier, S., X. Zhao, and P. Lacasse. 2014. Effects of feed restriction and prolactin-release inhibition at drying off on metabolism and mammary gland involution in cows. J. Dairy Sci. 97:4942-4954. https:/ /doi.org/10.3168/jds.2014-7914.

Persson Waller, K., and T. Westermark., TEkman, and K. Svennersten-Sjaunja. 2003. Milk leakage-An increased risk in automatic milking systems. J. Dairy Sci. 86:3488-3497. https://doi.org/10 .3168/jds.S0022-0302(03)73953-8.

Rajala-Schultz, P. J., J. S. Hogan, and K. L. Smith. 2005. Short communication: Association between milk yield at dry-off and probability of intramammary infections at calving. J. Dairy Sci 88:577-579. https://doi.org/10.3168/jds.S0022-0302(05)72720-X. 
Rovai, M., M. T. Kollmann, and R. M. Bruckmaier. 2007. Incontinentia lactis: Physiology and anatomy conducive to milk leakage in dairy cows. J. Dairy Sci. 90:682-690. https://doi.org/10.3168/jds .S0022-0302(07)71551-5.

Schukken, Y. H., F. J. Grommers, D. Van de Geer, H. N. Erb, and A. Brand. 1990. Risk factors for clinical mastitis in herds with a low bulk milk somatic cell count. 1. Data and risk factors for all cases. J. Dairy Sci. 73:3463-3471. https://doi.org/10.3168/jds .S0022-0302(90)79045-5.

Schukken, Y. H., F. J. Grommers, D. Van de Geer, H. N. Erb, and A. Brand. 1991. Risk factors for clinical mastitis in herds with a low bulk milk somatic cell count. 2. Risk factors for Escherichia coli and Staphylococcus aureus. J. Dairy Sci. 74:826-832. https://doi .org/10.3168/jds.S0022-0302(91)78231-3.

Schukken, Y. H., J. Vanvliet, D. Vandegeer, and F. J. Grommers. 1993. A randomized blind trial on dry cow antibiotic infusion in a low somatic cell count herd. J. Dairy Sci. 76:2925-2930. https:// doi.org/10.3168/jds.S0022-0302(93)77632-8.

Sordillo, L. M., and S. C. Nickerson. 1988. Morphometric changes in the bovine mammary gland during involution and lactogenesis. Am. J. Vet. Res. 49:1112-1120.

Sørensen, J. T., and C. Enevoldsen. 1991. The effect of dry period length on milk production in subsequent lactation. J. Dairy Sci. 74:1277-1283. https://doi.org/10.3168/jds.S0022-0302(91)78283 -0 .

Steeneveld, W., A. De Prado-Taranilla, K. Krogh, and H. Hogeveen. 2019. The economic impact of drying off cows with a dry-off facilitator (cabergoline) compared with 2 methods of gradual cessation of lactation for European dairy farms. J. Dairy Sci. 102:7483-7493. https://doi.org/10.3168/jds.2018-16068.

Stefanon, B., M. Colitti, G. Gabai, C. H. Knight, and C. J. Wilde. 2002. Mammary apoptosis and lactation persistency in dairy animals. J. Dairy Res. 69:37-52. https://doi.org/10.1017/S0022029901005246.

Tančin, V., B. Ipema, P. Hogewerf, and J. Mačuhová. 2006. Sources of variation in milk flow characteristics at udder and quarter lev- els. J. Dairy Sci. 89:978-988. https://doi.org/10.3168/jds.S0022 -0302(06)72163-4.

Thornton, P. K. 2010. Livestock production: Recent trends, future prospects. Philos. Trans. R. Soc. Lond. B Biol. Sci. 365:2853-2867. https://doi.org/10.1098/rstb.2010.0134.

Tucker, C. B., S. J. Lacy-Hulbert, and R. J. Webster. 2009. Effect of milking frequency and feeding level before and after dry off on dairy cattle behavior and udder characteristics. J. Dairy Sci. 92:3194-3203. https://doi.org/10.3168/jds.2008-1930.

Vilar, M. J., M. Hovinen, H. Simojoki, and P. J. Rajala-Schultz. 2018. Drying-off practices and use of dry cow therapy in Finnish dairy herds. J. Dairy Sci. 101:7487-7493. https://doi.org/10.3168/jds .2018-14742.

Weber, C., B. Losand, A. Tuchscherer, F. Rehbock, E. Blum, W. Yang, R. M. Bruckmaier, P. Sanftleben, and H. M. Hammon. 2015. Effects of dry period length on milk production, body condition, metabolites, and hepatic glucose metabolism in dairy cows. J. Dairy Sci. 98:1772-1785. https://doi.org/10.3168/jds.2014-8598.

Weiss, D., M. Weinfurtner, and R. M. Bruckmaier. 2004. Teat anatomy and its relationship with quarter and udder milk flow characteristics in dairy cows. J. Dairy Sci. 87:3280-3289. https://doi.org/ 10.3168/jds.S0022-0302(04)73464-5.

WHO. (World Health Organisation). 2015. Global Action Plan on Antimicrobial Resistance. WHO, Geneva, Switzerland.

Zobel, G., K. Leslie, D. M. Weary, and M. A. G. von Keyserlingk. 2013. Gradual cessation of milking reduces milk leakage and motivation to be milked in dairy cows at dry-off. J. Dairy Sci. 96:5064-5071. https://doi.org/10.3168/jds.2012-6501.

Zobel, G., D. M. Weary, K. E. Leslie, and M. A. G. von Keyserlingk. 2015. Invited review: Cessation of lactation: Effects on animal welfare. J. Dairy Sci. 98:8263-8277. https://doi.org/10.3168/jds.2015 $-9617$. 